between 1948 and 1952. Incidence, clinical aspects, pathology, aetiology, prophylaxis, and treatment are each considered in turn. An interesting contribution is the use of slit-lamp microscopy by means of which an increased aqueous protein content without increase in cells in the anterior chamber may be observed in the active phase of retrolental fibroplasia. New-vessel formation on the iris is also mentioned, and the notion of anoxia $s$ a causative agent is favoured.

The second section comprises a valuable account of the differential diagnosis of retinoblastoma and retrolental fibroplasia: it is unfortunate that the unhappy term " pseudoglioma " is used in the title of this section of the book (and also frequently in the text) in view of the high standard of thought and observation, clinical and pathological, with which these several conditions are described. The following conditions are described and illustrative case reports appended in each instance: hypertrophy of primary vitreous, ablatio falciformis retinae, retinal dysplasia, metastatic ophthalmia, tuberculosis, toxoplasmosis, exudative retinitis of Coats.

The essential points of differential diagnosis are given in the short third section.

In general, this book is a valuable contribution to an important subject, and it is a pity that the nine plates are not of uniform quality.

\title{
NOTES
}

\section{Ophthalmological Society of THE United Kingdom}

THE society holds a considerable stock of certain volumes of the Transactions since their first publication in 1881 . The Council would be glad to present to members such available volumes as they may desire. No charge will be made beyond the cost of packing and postage. The volumes available are:

$\begin{array}{cccccc}\text { Volume } & \text { Date } & \text { Volume } & \text { Date } & \text { Volume } & \text { Date } \\ 1 & 1881 & 7 & 1887 & 35 & 1915 \\ 2 & 1882 & 8 & 1888 & 45 \mathrm{pt.} 1 & 1925 \\ 3 & 1883 & 9 & 1889 & 45 \mathrm{pt.} 2 & 1925 \\ 4 & 1884 & 11 & 1891 & 61 & 1941 \\ 5 & 1885 & 12 & 1892 & 67 & 1947 \\ 6 & 1886 & 33 & 1913 & 68 & 1948\end{array}$

Applications, which will be dealt with in rotation, should be sent to the Honorary Secretary, Ophthalmological Society of the United Kingdom, 45 Lincoln's Inn Fields, L ondon, W.C.2, before July 31, 1953.

\section{South Western Ophthalmological Society-Southern OPHTHALMOLOGICAL SOCIETY}

The joint meeting at the Bristol Eye Hospital, Bristol, which was planned for May 9, has been postponed to Saturday, May 30, at 2.15 p.m.

$\left.\begin{array}{l}\text { Anthony Palin } \\ \text { Nigel Cridland }\end{array}\right\}$ Hon. Secretaries.

\section{Royal Eye Hospital Clinical Society}

THE March meeting will be held at the Hospital on Wednesday, March 25, 1953, at 8 p.m. Mr. Murray A. Falconer will speak on "Visual Field Changes in Compressions of the Optic Nerve, Chiasm, and Tract".

\section{CORRIGENDUM}

British Journal of Ophthalmology (1953), 37, 125, line 6: for "glaucomatous" read "trachomatous". 